\title{
FACTORS AFFECTING WATER QUALITY IN A WATER SUPPLY NETWORK
}

\author{
Artur Jachimowski ${ }^{1}$ \\ 1 Department of Technology and Ecology of Products, Faculty of Commodity Science, Cracow University of \\ Economics, Rakowicka 27, 31-510 Kraków, Poland, e-mail: artur.jachimowski@uek.krakow.pl
}

Received: 2017.05.03

Accepted: 2017.05.31 Published: 2017.07.01

\begin{abstract}
An effect of factors determining water quality in the water supply network in Kraków is assessed. The data collected over a four-year research period included quality parameters of water taken from the water distribution system in the period between 1 January 2011 and 31 December 2014. In the analysis the supply zones of four municipal water treatment plants in Krakow were considered. The selection of 29 water sampling points within the supply area allowed comparing water quality with respect to operational and technological aspects. Factor analysis enabled 4 components explaining correlations between tap water quality variables to be distinguished. It follows from the research performed that the obtained factors applied to $77 \%$ of overall water variability. The highest share was assigned to factor 1 that explained $32 \%$ of the chemical composition of water under consideration and was correlated with calcium, conductance, nitrates (V), magnesium and to a moderate extent with $\sum$ THM (with negative sign).
\end{abstract}

Keywords: factor analysis, secondary contamination of water, water supply network, water quality

\section{INTRODUCTION}

In water distribution systems both physicochemical and microbiological indices can change. There are a lot of factors that have an effect on secondary contamination of water that can be supplied to consumers. The type and intensity of processes occurring within water supply systems decide on the form of contamination (suspended, colloidal or dissolved). However, the type of concentration of contaminants penetrating into water depend on the amount and chemical composition of deposits in a water supply system, the number and kind of microorganisms living in biofilms, microbial metabolic pathways, biochemical processes and stability of flowing water [Kowal and Świderska-Bróż 2009, Pierścieniak 2009].

Chemical and microbiological stability of water in distribution systems is affected by the raw water quality [Jachimowski 2016] and reliability of treatment processes. Therefore, the main problem of all water supply systems is the loss of wa- ter stability during the transmission from water treatment plant to customer [Łomotowski 2007, Kowal and Świderska-Bróż 2009].

Water is considered as chemically stable when it does not cause the precipitation of deposits, mainly calcium carbonate $\left(\mathrm{CaCO}_{3}\right)$ [ŚwiderskaBróż and Wolska 2006, Biłozor et al. 2010]. The main indicators of contamination for chemically unstable water in the water distribution system are total iron and related turbidity, colour and the use of free chlorine [Świderska-Bróż i Wolska 2005]. However, biologically stable water does not support microbial growth. This is connected with the lack of organic and inorganic nutrients enabling microbial growth [Świderska-Bróż 2003, Świderska-Bróż and Wolska 2006, Kowal and Świderska-Bróż 2009, Biłozor et al. 2010].

Secondary bacterial growth in the water supply system imposes high doses of disinfection agents to be used to inhibit microbial growth. This is why the kind and concentration of disinfectant used depend on the number of microorganisms 
and their resistance to a specified agent, pipeline material and deposits that use disinfectant [Kowal, Świderska-Bróż 2009]. Water supply tubing is an ideal habitat both for heterotrophic and autotrophic bacteria. However, the development of biofilm depends on the quality of water flowing through the pipe network. The presence of assimilable organic carbon in water is a factor limiting the growth of heterotrophic microorganisms [Łomotowski 2007].

During the transmission of water in water supply networks a deterioration of its taste and odour and increased colour and turbidity indices are often observed. There is also a risk of an increase in the number of indicator bacteria. In addition, in water disinfected with chlorine or chlorine dioxide the amount of disinfection by-products increases. Also, iron and manganese concentrations increase and water $\mathrm{pH}$, hardness and alkalinity change [Łomotowski 2007, Bergel et al. 2013].

The aim of this paper is to determine an effect of some factors on water quality in the distribution system of the Water Treatment Plants at the Municipal Water Supply and Sewerage Plant in Kraków.

Application of factor analysis to identify the origin of chemical composition of water intended for human consumption is presented. This is a complex problem as water production is based on 4 water treatment plants (Raba, Rudawa, Dłubnia and Bielany) that use surface waters as a source of drinking water, except for one deep water intake. The analysis made in the years 2011 to 2014 pertained to selected physicochemical parameters determined in selected points of the water supply network.

\section{SECONDARY CONTAMINATION OF WATER IN DISTRIBUTION SYSTEM}

The cause of deteriorating water quality may be sediments which build up on the inside of pipelines. The research performed has shown that iron sediments may occur inside water supply pipelines at iron concentration of $0.05 \mathrm{mg} \cdot \mathrm{dm}^{-3}$. This leads to an increase in iron concentration despite of good water chemical composition when pumping water into the network. This is caused by picking off sediments due to changes in water flow direction or rate in water distribution network and iron penetration into water by its dissolution. It has been demonstrated that in the latter case an appropriate oxygenation can inhibit the diffusion of $\mathrm{Fe}(\mathrm{II})$ from the sediment into tap water [Weber 2010].

The quality of the treated water depends, to a large extent, on factors related to technical condition and the age of the water supply network [Gamrot et. al. 2001, Bergel 2012]. Pipe age that decides on failure rate is of special importance. A long period of use significantly accelerates the wear of pipe materials [Bergel et. al. 2013]. This increases the risk of water supply system failure [Tchórzowska-Cieślak 2010, Kwietniewski 2011, Rak and Tchórzowska-Cieślak 2013]. Hydraulic conditions in the water supply network (flow velocity, water pressure and too long water age as well as water supply outages have an important effect on the quality of water delivered to consumers [Świderska-Bróż and Wolska 2006].

One of the factors causing the deterioration of water supplied to customers is corrosion processes in outdoor and indoor water pipes. Corrosion is enhanced by the presence of aggressive carbon dioxide in water that deteriorates the passive films (oxide coatings). Corrosion rate is affected not only by water pipeline materials but also by physicochemical composition of water. The effect of corrosion is the deterioration of water supply network materials and enrichment of water delivered to customers with dissolved forms of metals. Therefore, the quality of water delivered to consumers depends primarily on processes that occur in the water distribution system. The water corrosivity index plays an important role in these processes [Januszewska et al. 2011].

Biofilms may be formed on the inner walls of water supply pipelines. They may increase the risk of microbiological contamination of water. As follows from the research carried out, the strongest water quality changes related to corrosion and biofilms will occur in indoor water supply systems of small diameter pipes.

In the water disinfection process chlorine water or chlorine dioxide solutions are used. Some water supply plants use sodium hypochlorite.

The process of disinfectant decay in water involves two stages. The first stage occurs directly after the disinfectant is put into water and lasts from a few minutes to several hours depending on water composition and temperature. The rate of disinfectant decay is affected by its relations with organic and mineral compounds susceptible to oxidation [Łomotowski 2007]. At the second stage the rate of chlorine decay in water is characterized by a first-order reaction (first-order kinetics) [Haas and Karra 1984, Kiéné and Lévi 1998]. 
The key task of collective water supply systems is to provide inhabitants with healthy water [Act of 7 June 2001]. However, this objective is not always achieved. This is observed in deteriorating water quality in distribution systems for many years. There are various causes of secondary contamination of water delivered to customers. They may occur individually or coexist and interact, thus deteriorating the quality of water transferred in distribution systems. The thorough analysis allowed identification of the crucial factors involved. When classifying them the full range of causes of secondary contamination in the network was considered and the factors of especially strong influence on water quality (according to its severity) were highlighted [Kwietniewski et. al. 2012]. When considering the above assumptions the following division has been proposed, as presented in Table 1.

The factors listed above do not always affect individually the quality of water transferred in the network. A single factor may often cause changes in water quality in various areas of influence [Kwietniewski et. al. 2012].

However, Bergel and other researchers divide the factors affecting tap water quality into two categories: external and internal ones. The external ones include water contamination during failures and its resolving, expanding the pipelines and operation and repairs. The inner ones include sediment accumulation in pipes, sediment loosening, pipe corrosion, chemical reactions in water, microbial growth on pipe walls and biological contamination (the so called biofilm) [ŚwiderskaBróż and Wolska 2007, Bergel et. al. 2009].

\section{RESEARCH METHODOLOGY}

The object of this study was to perform statistical analysis of laboratory water test results in the distribution network in Kraków. The determination of tap water physicochemical parameters was carried out in the years $2011-2014$. Test samples were taken at a specified point of the network on average every three months every year (Table 2). The mean values were computed from the results obtained over an 8-year period. The results of determination were made available from the Central Laboratory of the MPWiK S.A. of Kraków [Central Laboratory MPWiK S.A. 2015], and selected indices were determined according to the research method register [Central Laboratory MPWIK S.A. 2013].

The samples of treated water for laboratory testing were taken at points located in various Kraków districts. There were primarily public facilities such as schools, kindergartens, shops, petrol stations and offices.

The basic statistical parameters, i.e. mean, minimum and maximum values, standard deviation and coefficient of variation were calculated for selected tap water quality parameters.

To identify processes deciding on the chemistry of water taken and treated by the ZUW factor analysis, principal component method was used. This technique allows the variability of all water parameters under examination to be analysed simultaneously, and various sources of tap water contamination to be extracted as factors. Another possibility is to determine the percentage share of theses sources in forming water chemical composition [Modelska and Burzyński 2007].

Table 1. Factors causing secondary contamination in water supply networks

\begin{tabular}{|l|l|}
\hline \multicolumn{1}{|c|}{ Factor classes } & \multicolumn{1}{c|}{ Examples of factors } \\
\hline Water-related factors & $\begin{array}{l}\text { - Effectiveness of water treatment processes in water supply systems } \\
\text { - Disinfection by-products } \\
\text { - Lack of water biostability and consequential microbial growth } \\
\text { - Lack of water biostability and resulting corrosivity and sediment accumulation }\end{array}$ \\
\hline $\begin{array}{l}\text { Factors connected with hydraulic conditions } \\
\text { in the network }\end{array}$ & $\begin{array}{l}\text { - Water flow velocity } \\
\text { - Water ceasing to flow and stagnation in the network } \\
\text { - Pressure variations }\end{array}$ \\
\hline Operational factors & $\begin{array}{l}\text { - Pipe age } \\
\text { - Presence of sediments }\end{array}$ \\
\hline $\begin{array}{l}\text { Factors related to pipe material and } \\
\text { tightness }\end{array}$ & $\begin{array}{l}\text { - Network failure rate } \\
\text { - Operational negligence }\end{array}$ \\
\hline Factors related to network structure & - Types of pipe material, sealing and protective coatings \\
\hline
\end{tabular}

Source: based on [Kwietniewski et. al. 2012] 
Table 2. Water sampling points in the municipal water supply network in Kraków in the years 2011-2014

\begin{tabular}{|c|c|c|c|c|c|}
\hline Item & Sampling point & Supply area & Item & Sampling point & Supply area \\
\hline 1 & ul. Zarzecze 106 - fire department & \multirow{6}{*}{ ZUW Rudawa } & 16 & $\begin{array}{l}\text { ul. Kutrzeby } 4 \text { - NZOZ Kraków } \\
\text { Południe (Central Laboratory) }\end{array}$ & \multirow{5}{*}{ ZUW Raba } \\
\hline 2 & $\begin{array}{l}\text { ds. Sosnowa } 8 \text { - Sera and } \\
\text { Vaccines Manufacturing Company }\end{array}$ & & 17 & $\begin{array}{l}\text { ul. Kosiarzy } 1 \text { - } \\
\text { MPWiK - Sewage Treatment } \\
\text { Plant }\end{array}$ & \\
\hline 3 & ul. Stawowa 179 - school & & 18 & $\begin{array}{l}\text { Rynek Podgórski } 1 \text { - Kraków } \\
\text { City Council }\end{array}$ & \\
\hline 4 & $\begin{array}{l}\text { ul. Tokarskiego } 1 \\
\text { - DS “Akropol” (dormitory) }\end{array}$ & & 19 & $\begin{array}{l}\text { ul. Komandosów } 1 \text { - SM } \\
\text { Podwawelska }\end{array}$ & \\
\hline 5 & $\begin{array}{l}\text { ul. Nałkowskiego } 1 \text { - health care } \\
\text { centre }\end{array}$ & & 20 & $\begin{array}{l}\text { ul. Stoczniowców } 7 \\
\text { - health care centre }\end{array}$ & \\
\hline 6 & ul. Łokietka 177 - Energoprzem & & 21 & ul. Kantorowicka 77 - bakery & \multirow{4}{*}{ ZUWDłubnia } \\
\hline 7 & $\begin{array}{l}\text { ul. Poronińska } 7 \text { - Samorządowe } \\
\text { Przedszkole nr } 145\end{array}$ & \multirow{9}{*}{ ZUW Raba } & 22 & $\begin{array}{l}\text { os. Złotej Jesieni } 1 \text { - WSS im. } \\
\text { L. Rydygiera }\end{array}$ & \\
\hline 8 & $\begin{array}{l}\text { ul. Chałubińskiego } 21 \text { - sklep } \\
\text { ogólnospożywczy „Olimp” }\end{array}$ & & 23 & os. Górali 5 - Dom Kultury & \\
\hline 9 & $\begin{array}{l}\text { ul. Stojałowskiego } 1 \text { - petrol } \\
\text { station }\end{array}$ & & 24 & os. Na Skarpie 8 - szkoła & \\
\hline 10 & ul. Cechowa 57 - school & & 25 & ul. Mirowska 278 - RZGW & \multirow{6}{*}{ ZUW Bielany } \\
\hline 11 & $\begin{array}{l}\text { ul. Babińskiego } 29 \text { - Krakowski } \\
\text { Szpital Neuropsychiatryczny }\end{array}$ & & 26 & ul. Astronautów 5 - sklep & \\
\hline 12 & $\begin{array}{l}\text { ul. Spółdzielców 3, Spółdzielnia } \\
\text { Mieszkaniowa na Kozłówce, }\end{array}$ & & 27 & $\begin{array}{l}\text { ul. Kamedulska } 70 \text { - health } \\
\text { care centre }\end{array}$ & \\
\hline 13 & $\begin{array}{l}\text { ul. Bieżanowska } \\
40 \text { - kindergarten }\end{array}$ & & 28 & \begin{tabular}{|l|} 
Tyniec, ul. Bolesława \\
Śmiałego 7
\end{tabular} & \\
\hline 14 & ul. Brożka 3 - M.P.K. & & \multirow{2}{*}{29} & \multirow{2}{*}{ Las Wolski - ZOO } & \\
\hline 15 & ul. Gronostajowa 3 - kampus UJ & & & & \\
\hline
\end{tabular}

The principal component analysis was used also to examine the water produced by 4 water treatment plants (Raba, Rudawa, Dłubnia and Bielany) that employ a highly advanced treatment technology [Adamczyk and Jachimowski 2014]. This is why only these parameters that had sufficient representations and showed diversification were used.

\section{RESULTS AND DISCUSSION}

The most important cause of secondary contamination of water introduced into the distribution network from the treatment plant is the lack of its biological and chemical stability. However, there are conditions enhancing bacterial growth and sedimentation dissolution in stable drinking water.

The following physicochemical indices were determined in tap water: free chlorine, colour, turbidity, $\mathrm{pH}$, conductivity, iron, aluminium, sodium, ammonium ion, potassium, magnesium, calcium, $\sum$ chlorates(V) and chlorates(III), fluorides, chlorides, nitrates(III), nitrates(V), phosphates(V), sulphates(VI), copper, total organic carbon (TOC), इTHM (total trihalomethanes). For the above parameters the most important factors responsible for water quality changes in the distribution system are presented in (Fig. 1). It follows from the correlation matrix of factor loadings that the examined waters from Rudawa, Dobczyce Reservoir, Dłubnia and Sanka differ in the number and share of extracted factors (Table 3).

Table 3. Rotated component matrix - tap water

\begin{tabular}{|c|c|c|c|c|}
\hline \multirow{2}{*}{ Index } & \multicolumn{4}{|c|}{ Component } \\
\hline & 1 & 2 & 3 & 4 \\
\hline Conductivity & 0.955 & & & \\
\hline Calcium & 0.949 & & & \\
\hline Nitrates & 0.896 & & & \\
\hline Magnesium & 0.825 & & & \\
\hline$\sum$ THM & -0.746 & & & \\
\hline Turbidity & & 0.939 & & \\
\hline Colour & & 0.888 & & \\
\hline Iron & & 0.877 & & \\
\hline Sodium & & & 0.826 & \\
\hline TOC & & & 0.805 & \\
\hline Aluminium & & & -0.756 & \\
\hline Free chlorine & & & & 0.790 \\
\hline Ammonium ion & & & & 0.714 \\
\hline $\begin{array}{l}\text { Percent } \\
\text { contribution in } \\
\text { variability }\end{array}$ & 32 & 20 & 16 & 9 \\
\hline
\end{tabular}

Source: own research based on the MPWiK results 


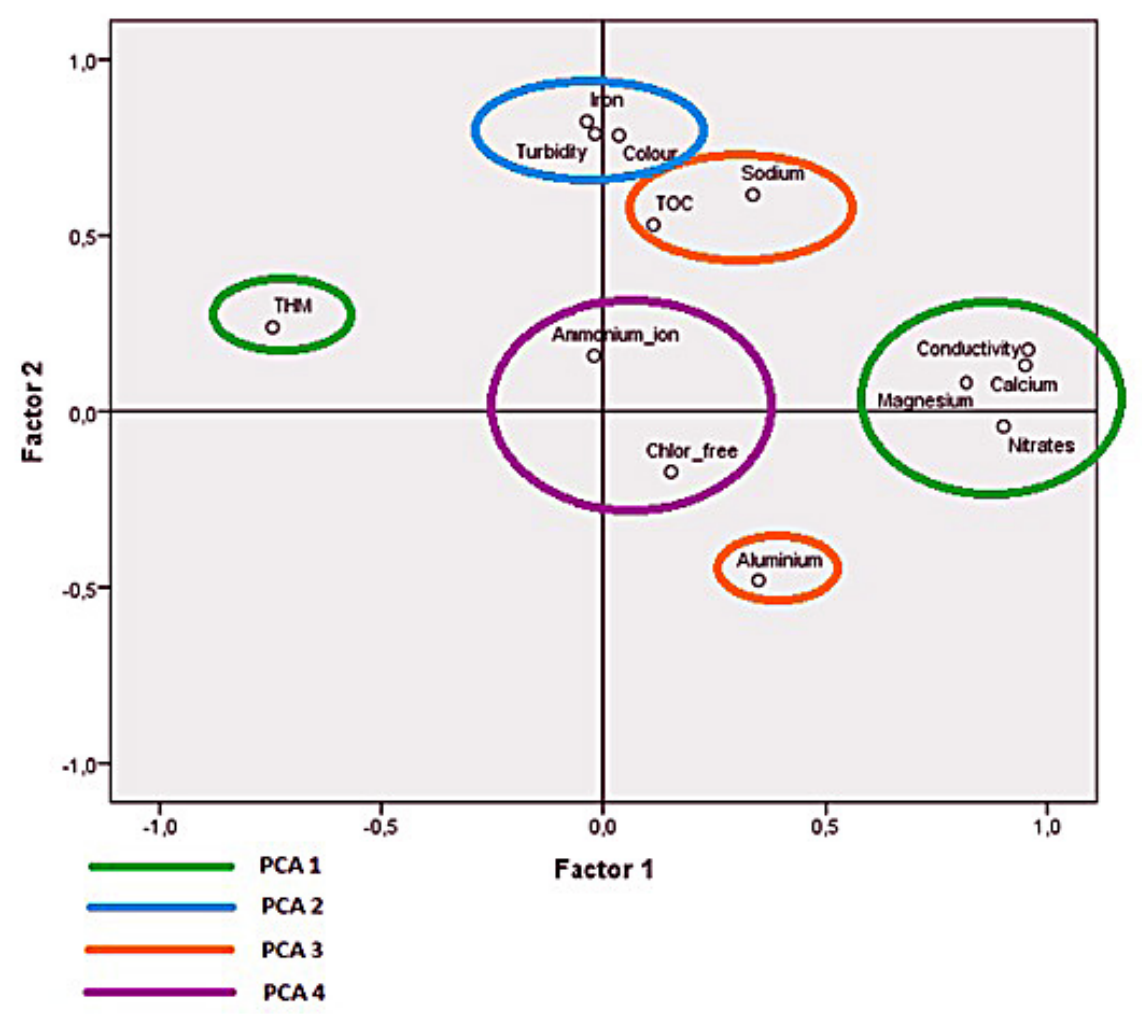

Fig. 1. Plot of factor loadings for tap waters in the years 2011-2014

Source: own research based on the MPWiK results

The analysis of waters coming from 4 main supply areas of the city of Kraków enabled 4 factors that explain $77 \%$ of its chemical composition to be isolated. Based on factor loadings of water withdrawn at specified points of the water supply network factor 1 that explains $32 \%$ of water chemical composition was isolated. During the analysis it was highly correlated with the following indices: calcium, conductivity, nitrates $(\mathrm{V})$, magnesium and moderately with $\sum$ THM (with negative sign). These indices have the largest contribution in multi-feature differentiation of tap water quality. The values of factor loadings indicate that water that contained a relatively large amount of nitrates $(\mathrm{V})$ had both higher conductivity and total hardness (sum of $\mathrm{Ca}^{2+}$ and $\mathrm{Mg}^{2+}$ ions). However, soft waters of the lowest conductivity among all examined samples had a relatively high concentration of disinfection by-products, i.e. $\sum$ THM. These waters were produced at the ZUW Raba where gaseous chlorine is used.

Factor 2 that explains $20 \%$ variability of chemical composition is characterised by a strong correlation with turbidity, colour and iron. This indicates that the number of colour units increased with increasing iron concentration. Iron cause water to turn a reddish brown colour and give water an unpleasant taste and odour and stimulates bacterial growth. In addition, the presence of iron compounds in drinking water causes turbidity that enhances microbial growth.

Factor 3 representing $16 \%$ of variability is strongly correlated with sodium, total organic carbon and aluminium (minus sign). This indicates that the use of aluminium coagulants promotes removal of organic substances from water of lower sodium ion concentrations.

For Factor 4 that explains 9\% of water chemical composition, there is a strong relationship with free chlorine and a moderate with ammonium nitrogen. The content of ammonium nitrogen is an important factor from the chlorine disinfection efficiency, as it forms chloramines in reaction with chlorine.

The principal component analysis carried out forms a general assessment model for water quality in the water supply system of the city of Kraków. This consists in determining quite new variables (principal components) to explain chemical composition variations for the examined water. Each of isolated factors has been represented as a linear combination of the original variables. 


\section{AN ASSESSMENT OF WATER QUALITY IN A WATER SUPPLY NETWORK}

The water quality indices at selected points of the water supply network that correspond to a specified plant were evaluated. Monitoring covered the period between 2011 and 2014. The values of microbiological and physicochemical parameters were compared with guidelines contained in the Regulation of the Minister of Health on quality requirements for water intended for human consumption [Regulation of the Minister of Health of 13 November 2015].

When assessing the quality of water taken into the water supply network of the city of Kraków it should be concluded that monthly means of analysed physicochemical indices in the period under investigation meet the requirements of national [Regulation of the Minister of Health of 13 November 2015] and European standards [EU Directive 98/83/EC of 3 November 1998]. It follows from the conducted research that the water produced at the ZUW Raba was of the best quality - the lowest values of physicochemical indices compared to those of other plants [Adamczyk and Jachimowski 2012].

The maximum values of tap water quality indices are presented in Table 4.

In water intended for consumption the values of microbiological indices, i.e. group of coliform bacteria, Escherichia coli, Enterococcus and Clostridium perfringens should be $0 \mathrm{cfu}$ in $100 \mathrm{ml}$ of

Table 4. An assessment of water quality in the municipal water supply network in Kraków in the years 2011-2014

\begin{tabular}{|c|c|c|c|c|c|}
\hline Index & Unit & TLV & Max & $\begin{array}{l}\text { Number of } \\
\text { exceedings }\end{array}$ & Location of exceedings \\
\hline Coliform bacteria & $\mathrm{cfu} / \mathrm{ml}$ & 0 & 0 & 0 & No \\
\hline Escherichia coli & cfu/ml & 0 & 0 & 0 & No \\
\hline $\begin{array}{l}\text { Enterococcus (Enterococcus } \\
\text { feacalis) }\end{array}$ & $\mathrm{cfu} / \mathrm{ml}$ & 0 & 0 & 0 & No \\
\hline $\begin{array}{l}\text { Clostridium perfringens } \\
\text { (including spores) }\end{array}$ & $\mathrm{cfu} / \mathrm{ml}$ & 0 & 0 & 0 & No \\
\hline $\begin{array}{l}\text { Total number of microorganisms } \\
\text { at } 22^{\circ} \mathrm{C} \text { after } 72 \mathrm{~h}\end{array}$ & $\mathrm{cfu} / \mathrm{ml}$ & 100 & 370 & 5 & $\begin{array}{c}\text { Tokarskiego 1, Cechowa } \\
\text { 57,Gronostajowa 3, Kutrzeby 4, } \\
\text { Kosiarzy 1, Bolesława Śmiałego 7, } \\
\text { Las Wolski - ZOO }\end{array}$ \\
\hline Free chlorine & $\mathrm{mg} \cdot \mathrm{dm}^{-3}$ & 0.3 & 0.5 & 3 & $\begin{array}{c}\text { Babińskiego 29, Kamedulska 70, } \\
\text { Las Wolski - ZOO }\end{array}$ \\
\hline Colour & $\mathrm{mgPt} \cdot \mathrm{dm}^{-3}$ & 15 & 16 & 1 & Mirowska 278 \\
\hline Turbidity & NTU & 1 & 2.9 & 6 & $\begin{array}{c}\text { Cechowa 57, Mirowska 278, } \\
\text { Kamedulska } 70\end{array}$ \\
\hline Odour & & & acceptable & & No \\
\hline Taste & & & acceptable & & No \\
\hline $\mathrm{pH}$ & & 9.5 & 8.11 & 0 & No \\
\hline Specific conductivity at $25^{\circ} \mathrm{C}$ & $\mu \mathrm{S} \cdot \mathrm{cm}^{-1}$ & 2500 & 765 & 0 & No \\
\hline 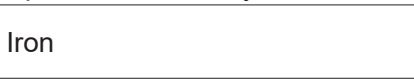 & $\mathrm{mg} \cdot \mathrm{dm}^{-3}$ & 0.2 & 0.49 & 7 & $\begin{array}{l}\text { Kutrzeby 4, Mirowska 278, } \\
\text { Las Wolski - ZOO }\end{array}$ \\
\hline Aluminium & $\mathrm{mg} \cdot \mathrm{dm}^{-3}$ & 0.2 & 0.117 & 0 & No \\
\hline Sodium & $\mathrm{mg} \cdot \mathrm{dm}^{-3}$ & 200 & 42.6 & 0 & No \\
\hline Ammonia & $\mathrm{mg} \cdot \mathrm{dm}^{-3}$ & 0.5 & 0.39 & 0 & No \\
\hline Potassium & $\mathrm{mg} \cdot \mathrm{dm}^{-3}$ & & 5.9 & & No \\
\hline Magnesium & $\mathrm{mg} \cdot \mathrm{dm}^{-3}$ & 125 & 18 & 0 & No \\
\hline Calcium & $\mathrm{mg} \cdot \mathrm{dm}^{-3}$ & & 135 & & No \\
\hline$\Sigma$ chlorates and chlorites & $\mathrm{mg} \cdot \mathrm{dm}^{-3}$ & 0.7 & 0.66 & 0 & No \\
\hline Fluorides & $\mathrm{mg} \cdot \mathrm{dm}^{-3}$ & 1.5 & 0.29 & 0 & No \\
\hline Chlorides & $\mathrm{mg} \cdot \mathrm{dm}^{-3}$ & 250 & 78 & 0 & No \\
\hline Nitrates (III) & $\mathrm{mg} \cdot \mathrm{dm}^{-3}$ & 0.5 & 0.2 & 0 & No \\
\hline Nitrates (V) & $\mathrm{mg} \cdot \mathrm{dm}^{-3}$ & 50 & 26.2 & 0 & No \\
\hline Phosphates (V) & $\mathrm{mg} \cdot \mathrm{dm}^{-3}$ & & 0.84 & & No \\
\hline Sulphates (VI) & $\mathrm{mg} \cdot \mathrm{dm}^{-3}$ & 250 & 109 & 0 & No \\
\hline Copper & $\mathrm{mg} \cdot \mathrm{dm}^{-3}$ & 2 & 0.02 & 0 & No \\
\hline TOC & $\mathrm{mg} \cdot \mathrm{dm}^{-3}$ & 5 & 4.57 & 0 & No \\
\hline$\Sigma$ THM & $\mu \mathrm{g} \cdot \mathrm{dm}^{-3}$ & 100 & 48.6 & 0 & No \\
\hline
\end{tabular}

Source: own research based on the MPWiK results 
examined water. The related requirements stipulated in the regulation were met. The total number of microorganisms at $22^{\circ} \mathrm{C}$ after $72 \mathrm{~h}$ should not exceed $100 \mathrm{cfu}$ per $100 \mathrm{ml}$ of water. These requirements have not been met at eight points of the water supply network, namely: Tokarskiego 1 (22 July 2014 - $130 \mathrm{cfu} / \mathrm{ml}$ ), Cechowa 57 (3 October 2012 - $134 \mathrm{cfu} / \mathrm{ml}$ ), Gronostajowa 3 (17 June 2014 - $104 \mathrm{cfu} / \mathrm{ml}$ ), Kutrzeby 4 (31 August $2011-370$ cfu/100 ml), Kosiarzy 1 (31 August $2011-110$ cfu/100 ml), Stoczniowców 7 (19 August 2014 - $180 \mathrm{cfu} / \mathrm{ml}$ ), Tyniec - Bolesława Śmiałego 7 (24 April 2013 - $112 \mathrm{cfu} / 100 \mathrm{ml}$ ) and Las Wolski - ZOO (24 April 2013 - $121 \mathrm{cfu} 100 \mathrm{ml}$ ).

If water is contains chlorine compounds exceeding the applicable standard, free chlorine should be kept at a level of $0.3 \mathrm{mg} \cdot \mathrm{dm}^{-3}$. The maximum permissible chlorine concentration in water was exceeded at: Babińskiego St. 29 (4 April $2012-0.50 \mathrm{mg} \cdot \mathrm{dm}^{-3}$ ), Kamedulska 70 (1 March $\left.2011-0.44 \mathrm{mg} \cdot \mathrm{dm}^{-3}\right)$ and Las Wolski - ZOO (13 February $2012-0.38 \mathrm{mg} \cdot \mathrm{dm}^{-3}$ ).

Water colour should be acceptable for consumers and show no abnormal changes. According to the regulation of the Minister of Health of 2007, the permissible value was set at 15 $\mathrm{mgPt} \cdot \mathrm{dm}^{-3}$. This limit has been exceeded only once - on 7 June 2011 at Mirowska St. 278 and was $16 \mathrm{mgPt} \cdot \mathrm{dm}^{-3}$.

According to legal regulations drinking water turbidity must be acceptable for consumers, and should show no abnormal changes and not exceed 1 NTU. This limit was exceeded once in water withdrawn at Cechowa 57 (31 July 2012 - 1.1 NTU), 5 times at Mirowska 278 (1 March 2011 - 1.5 NTU; 7 June 2011 - 2.9 NTU; 13 February $2012-1.5$ NTU; 9 May $2012-1.2$ NTU; 22 April 2014 - 2 NTU) and twice at Kamedulska 70 (7 June 2011 - 1.26 NTU; 22 April 2014 - 1.5 NTU).

Odour and taste of water intended for consumption by humans were acceptable for consumers and did not exceed permissible standards.

The examined water had $\mathrm{pH}$ ranging from 6.5 to 9.5 , i.e. compliant with the quality requirements. The highest $\mathrm{pH}$ of 8.11 was recorded in water taken at Stoczniowców St. on 19 November 2014.

According to standards, conductivity of clean water should be lower than $2500 \mu \mathrm{S} \cdot \mathrm{cm}^{-1}$. At sampling points this parameter did not exceed permissible values. The highest conductivity of $765 \mu \mathrm{Sm} \cdot \mathrm{dm}^{-3}$ was observed on 3 April 2012 at Tokarskiego St. 1.

Iron concentration should be kept at a level of $0.2 \mathrm{mg} \cdot \mathrm{dm}^{-3}$. An increased content of this element was found 8 times: one at Kutrzeby 4 (31 August $\left.2011-0.303 \mathrm{mg} \cdot \mathrm{dm}^{-3}\right), 5$ times at Mirowska 278 (1 March $2011-0.490 \mathrm{mg} \cdot \mathrm{dm}^{-3}$; 7 June $2011-0.382 \mathrm{mg} \cdot \mathrm{dm}^{-3} ; 13$ February $2012-0.479$ $\mathrm{mg} \cdot \mathrm{dm}^{-3} ; 9$ May $2012-0.204 \mathrm{mg} \cdot \mathrm{dm}^{-3} ; 22$ April $2014-0.308 \mathrm{mg} \cdot \mathrm{dm}^{-3}$ ) and twice at Las Wols$\mathrm{ki}-\mathrm{ZOO}$ (9 May $2012-0.219 \mathrm{mg} \cdot \mathrm{dm}^{-3}$; 16 January $\left.2013-0.228 \mathrm{mg} \cdot \mathrm{dm}^{-3}\right)$.

Other parameter, namely aluminium, sodium, ammonium nitrogen, potassium, magnesium, calcium, $\Sigma$ chlorates(V) and chlorates(III), fluorides, chlorides, nitrates(III), nitrates(V), sulphates(VI), copper, TOC and $\Sigma$ THM did not exceed permissible values stipulated in standards.

\section{CONCLUSIONS}

1. A plurality of factors determining drinking water quality causes that the quality is a function of many parameters that have a different and variable contribution in the final microbiological and physicochemical composition. The factors associated with water, hydraulic conditions in the network, pipe material and sealing and network structure play an important role.

2. Factor analysis enabled 4 components explaining a relationship between tap water quality indices to be distinguished. The obtained factors applied to $78 \%$ of total water variability. The highest share was assigned to factor 1 that explained in $32 \%$ the chemical composition of water under consideration and was correlated with calcium, conductance, nitrates(V), magnesium and to a moderate extent with $\sum$ THM (with negative sign).

3. Within the ZUW Dłubnia drinking water supply area an increase of $\sum$ THM concentration with increasing distance from the plant was observed. It follows from the analysis carried out that water disinfection by-products ( $\sum$ THM) did not exceed permissible limits.

4. An increase in iron concentration at specified points of the network may indicate corrosion of pipelines.

5. Secondary contamination of water in the water supply system occurred most often at the ZUW Bielany supply area at the following locations: Mirowska 278, Kamedulska 70 and ZOO - Las Wolski. This water was of poorest quality, but in any case still remained healthy. It follows from the conducted research that the pipe material has a stronger effect on water quality than the distance from the water treatment plant. 


\section{REFERENCES}

1. Adamczyk W., Jachimowski A. 2014. An effect of the Treatment Process on Drinking Water Quality in Cracow", [W:] Szakiel J. (edit.) Commodity Science in Research and Practice. Achievements and challenges of commodity science in the age of globalization. PolishSociety of Commodity Science. Cracow. Poland, 7-19.

2. Adamczyk W., Jachimowski A. 2012. Drinking water quality in the city of Kraków in the years 2007 - 2010, [W:] Żuchowski J., Zieliński R. (edit.) Role of innovativity in quality creation. Scientific Publishing House Institute for Technology of Exploitation - PIB. Radom, 188-200.

3. Bergel T., Kaczor G., Bugajski P. 2013. Technical conditions of water supply networks in small waterworks of the Małopolska and Podkarpackie Voivodeships. Infrastructure and ecology of rural areas, 3, 291-304.

4. Bergel T., Pawełek J., Rułka Z. 2009. Turbidity of water provided by the water supply systems in the Malopolskie Voivodeship. Environmental Pollution Control, 31, 4, 61-64.

5. Bergel T. 2012. An age and a materials structure of small grouped water-supplies in Poland. Gas, Water and Sanitary Engineering, 10, 416-418.

6. Biłozor S., Nawrocki J., Raczyk-Stanisławiak U., Świetlik J. 2010. Qualitative characteristics of natural waters [W:] Nawrocki J. (edit.) Water treatment: physical, chemical and biological processes. Part 1. Rev. 2. PWN Scientific Publishing House. Warsaw.

7. Central Laboratory MPWiK SA 2013. Register of research methods. Cracow.

8. Central Laboratory MPWiK SA 2015. Results of laboratory analyzes of water quality indicators made at the Central Laboratory in the years 2007 - 2014. Own research. Cracow.

9. EU Council Directive $98 / 83 /$ EC of 3 November 1998 on the quality of water intended for human consumption (Dz. U. L 330 of 5.12.1998), (http:// gis.gov.pl/ckfinder/userfiles/files/BW/98_83 WE.pdf), [access on 17-06-2015].

10. Gamrot B., Kuś K., Malicka K., Ścieranka G. 2001. Influence of technical and operating conditions of the water distribution system on water quality. Environmental Pollution Control, 3 (82), 17-20.

11. Haas C. N., Karra S. B. 1984. Kinetics of wastewater chlorine demand exortion, J. WPCF, 56, 2, 170-173.

12. Jachimowski A. 2016. Factors affecting water quality before treatment. Ecological Engineering, vol. 18, 1, 118-125. DOI: 10.12912/23920629/67003.

13. Januszewska A., Bojanowska I., Ryłko E., Miłosierna K. 2011. Influence of the chemical properties of water on its corrosivity. Water Technology, 3(11), 31-32.

14. Kiéné L., Lu W. Lévi Y. 1998. Relative importance of the phenomena responsible for chlorine decay in drinking water distribution systems, Wat. Scie. Tech., 38, 6, 219-227.

15. Kowal A. L., Świderska-Bróż M. 2009. Water purification. Theoretical and technological foundations, processes and devices. PWN Scientific Publishing House. Warsaw.

16. Kwietniewski M. 2011. Unreliability of water supply and wastewater infrastructure in Poland based on field tests. XXV Scientific-Technical Conference Building Failures. Miedzyzdroje., 127-140.

17. Kwietniewski M., Kowalska B., Wąsowski J., Chudzicki J., Kowalski D., Miszta-Kruk K. 2012. Problems of water quality management in distribution systems. Gas, Water and Sanitary Engineering, 3, 117-121.

18. Łomotowski J. 2007. Causes of water quality changes in water supply systems. System Research Institute of Polish Academy of Sciences. Warsaw.

19. Modelska M., Buczyński S. 2007. Application of factor analysis in hydrochemical research of selected Sudety Mts catchments. Geological Review, 55, 4,319-323.

20. Pierścieniak M., Trzcińska N., Słomczyński T, Wąsowski J. 2009. Problem of secondary contamination of water. Environmental Protection and Natural Resources, 39, 28-39.

21. Świderska-Bróż M., Wolska M. 2006. Major contributors to self-contamination of water in distribution systems. Environmental Pollution Control, 4, 29-34.

22. Świderska-Bróż M., Wolska M. 2005. The principal parameters of water quality deterioration in distribution system. Engineering and Protection of Environment, 8, 2, 159-169.

23. Świderska-Bróż M. 2003. Lack of Biological Stability and the Implication it has for Tap Water Quality. Environmental Pollution Control, 4, 7-12.

24. Świderska-Bróż M., Wolska M. 2007. Influence of hydraulic parameters on water pollution system. Environment Protection Engineering, 33, 4, 5-16.

25. Tchórzowska-Cieślak B. 2010. The risk of failure of water network. Gas, Water and Sanitary Engineering, 3, 38-41.

26. Act of 7 June 2001 on collective water supply and collective sewage disposal (i.e. Dz. U. z 2006 r., No. 123, item 858 with later amendments). (http://isap.sejm.gov.pl/Details Servlet?id=W DU20010720747), [access on 15-01-2016].

27. Weber Ł. 2010. Secondary pollution of tap water with iron. Causes and countermeasures on the example of the water supply system. Water Technology, 6, 33-37.

28. Rak J. R., Tchórzewska-Cieślak B. 2013. Risks in the operation of collective water supply systems. Seidel-Przywecki. Warsaw.

29. Regulation of the Minister of Health on quality requirements for water intended for human consumption (Dz. U. 2015 item 1989), (http://isap.sejm.gov. pl/DetailsServlet?id=WDU20150001989), [access on 10-01-2016]. 